\title{
The high representative's role in EU countering terrorism: policy entrepreneurship and thick, thin and global Europe
}

Joana de Deus Pereira \& Christian Kaunert

To cite this article: Joana de Deus Pereira \& Christian Kaunert (2020): The high representative's role in EU countering terrorism: policy entrepreneurship and thick, thin and global Europe, European Politics and Society, DOI: 10.1080/23745118.2020.1842695

To link to this article: https://doi.org/10.1080/23745118.2020.1842695

曲 Published online: 13 Nov 2020.

Submit your article to this journal $\pi$

山 Article views: 94

Q View related articles ¿

View Crossmark data \lceil 


\title{
The high representative's role in EU countering terrorism: policy entrepreneurship and thick, thin and global Europe
}

\author{
Joana de Deus Pereira and Christian Kaunert \\ International Centre for Policing and Security, University of South Wales, Wales, UK
}

\begin{abstract}
This article examines the role of the High Representative of the European Union for Foreign Affairs and Security Policy (HR) in the counter terrorism agenda and how it has been whittled according to the multiplicity and complexity of the several terrorism related crises in Europe, from Javier Solana to Federica Mogherini, following this special issue four faces taxonomy of Europe. It addresses how the different HRs explored terrorism as an existential threat and assesses their performance following Kingdon's policy entrepreneurship framework and Mintrom's research on policy entrepreneurship. It aspires to understand the hybrid nature and performance of the HRs as an institutional figure within the four faces of Europe framework and how the EU's complex institutional structure stretches policy boundaries and compels the use of different decision-making mechanisms to deal with domestic, external and foreign components of counterterrorism according to different materialisations of Europe's Self and Others.
\end{abstract}

\section{KEYWORDS}

EU; high representative; counter-terrorism; policy entrepreneurship; Europe

\section{Introduction}

Terrorism and counter-terrorism EU agenda was not only greatly influenced by the synchronisation of political will (Bickerton et al., 2015, pp. 708-9) to respond to the different momentums of the terrorist threats timeline, but has also been strongly shaped by the transfigurations and shape-shifting phases Europe has been suffering amid the supranational Vs intergovernmental debate. The different crisis and political transformations since the creation of the figure of the High Representative (later High Representative/Vice President) have echoed the existence of an European multiplicity (Biebuyck \& Rumford, 2012; Buhari-Gulmez \& Rumford, 2016; Rumford, 2014) that has been mirroring the existence of many and different voices within Europe, highlighting that the conceptualisation of a unified and unison European Union is becoming more and more elusive. Considering the immeasurable challenges posed by terrorism, there is a need to understand how the HR has managed to transform policy ideas into policy' innovations in the EU Counter-terrorism agenda, while adapting to the different challenges posed by thick, thin, parochial and global Europe. As a strongly emotional 
phenomenon, terrorism, has been a catalyst towards the idea of a thick 'Fortress Europe' (Buhari-Gulmez \& Rumford, 2016). However, the dynamics of the last 20 years, since 9/11 attacks, have demonstrated that the EU response to terrorism has been oscillating not only between Thick and Thin visions of Europe but, since the so-called migration crisis and the subsequent migration-terrorism nexus, has been echoing glimpses of parochial forms of Europe, reverberating nationalist and populist views such as the ones of Viktor Orban, Mateo Salvini or the recently ones confirmed by Brexit advocates. Framing the HR as a policy entrepreneur, we seek to examine how the different HRs have been projecting and portraying themselves differently from other counter-terrorism policy actors, using terrorist attacks in European soil as laboratory lenses to understand how these trigger events have been deepening the ideological divides of European multiplicity. Little focus has been given to how the specific attributes, skills and strategies of the three different HR have shaped the EU counter-terrorism policy. Theoretically, this article builds on John Kingdon's Multiple Stream Framework (MSF) and the approach by Michael Mintrom regarding the concept of policy entrepreneurship.

For our empirical analysis, we examine the links between the political opportunity created by the several terrorism attacks, the role of the Counter-Terrorism Coordinator, the European Commission's activity, and the policy change driven by the attribute skills and strategies of the HR. Ultimately, we seek to understand how policy entrepreneurship can be further integrated into the analysis of EU counter-terrorism policy and how it has been mirroring different faces of Europe according to the lead of each different HR. For this purpose, the article is divided as follows: first, borrowing from Biebuyck, Rumford and Buhari-Gulmez framework that there are many 'Europes beyond Europe' (Biebuyck \& Rumford, 2012; Buhari-Gulmez \& Rumford, 2016) we will examine how each face of Europe understands the terrorist attacks and how it responds and defends itself differently according to thick, thin, parochial and global solutions. Secondly, inspired on Kingdon, we will use the policy entrepreneurship framework to analyse how EU counter-terrorism policy is generated, allying the seven skills of a policy entrepreneur, enumerated by Mintrom. They are strategic thinking, team building, evidence collection, making arguments, engaging multiple audiences, negotiating, and networking (Mintrom, 2019a; Mintrom \& Luetjens, 2017; Mintrom \& Norman, 2009). Thirdly, we explore how the HR capitalises on the political opportunity space created by the terrorist events and how they respond. Finally, this article will outline the importance of the different strategies followed by the HRs as policy entrepreneurs as an attempt to shed the light on how the HRs have been acting as a facilitator of change within the political opportunity space and how the EU Counter-Terrorism agenda has been shaped by the different voices and visions of Europe.

\section{EU counter-terrorism policy through the lenses of European multiplicity}

The evolution of EU counter-terrorism policy is an excellent lens to observe how terrorism in European soil has been acting as a disruptor and how has been echoing the complex transformations and mutations Europe has been suffering since 9/11. Almost all EU counter-terrorism policy has been triggered by events - terrorist events - and this has highlighted the need to acknowledge that the basic binomial differentiation between Eurocentric/Europhile views of Europe are no longer ample to examine the complexity 
of the policy dynamics within the EU, especially when examining terrorism as a phenomenon that is simultaneously local, European and global. Terrorism has emphasised the existence of many clashes within Europe that did not surfaced until the first terrorist attack in Europe, in Madrid 2004 and, as a laboratory policy object, may be used to observe the changes of functional integrationism, civilization-based regionalism, nationalism, and globalism and how the EU has been designing its EU CT policy agenda according to a thin, thick and global Europe, despite many glimpses of parochial voices of Europe throughout the process.

We argue that the EU CT policy agenda has been profoundly shaped by three factors: unpredictability, brutality and disruptiveness, that generate a synchronised sentiment of fear that prompts EU policy mechanisms. The cause-effect links between terrorism and fear are well known and have been widely discussed in previous works (Huddy et al., 2003, 2003; Stout, 2004, chap. 2; Bongar et al., 2006). However, they are crucial when analysing the problem framing strategies employed by the HR not only as an effective policy broker, but also as an actor voicing distinct faces of Europe. Furthermore, once EU CT policies are innately linked to the idea of building and strengthening the resilience of the EU, it is worthwhile to understand that the perceptions of fear of terrorism in Europe have been oscillating according to the level of threat and to the mutating nature of terrorism itself. The modus operandi, the nature and the effects of terrorist attacks have been evolving since 9/11 and so has the EU CT agenda (Andreeva, 2019; Argomaniz et al., 2015; Bossong, 2012; Bures, 2006; Chalk, 1996a; Coolsaet, 2010; Kaunert, 2010a). Admittedly, fear management is of particular interest when examining the strategies and processes inherent to the conceptualisation of EU counter-terrorism policies. Bakker and de Graaf embryonic academic work on the formulation of a future 'Theory of Fear Management in the Counter-terrorism Domain' (Bakker, 2012; Bakker \& Graaf, 2014) underline the importance of this element for the development of counter-terrorism policies.

As we will examine in the following sections, the initial EU response to the terrorist attacks in Madrid and London (2004-2005) by HR Javier Solana was profoundly linked to the urgency of defending the European civilizational status, the Judaeo-Christian matrix, the values of the EU, as well as the idea that the Fortress Europe could respond undivided under a supposedly strong European Identity. This resonated with the idea of a thick Europe - a problem-solver under the cores of Europe as a moral superior and guardian of liberal democracy and rule of law, anchored by common historical roots, cultural and historical empathies (Buhari-Gulmez \& Rumford, 2016). However, the depth of this face of Europe soon revealed its inner fragilities the more it overlooked the panoply of particularities and differences within Europe, and the more it considered Others as an existential threat (especially when observing the much-explored causational link Muslim=terrorist). However, after the profound changes introduced by the Treaty of Lisbon with the creation of the European External Action Service (EEAS), a much Thin Europe emerged to respond to a functional differentiation and territorial segmentation dynamics imposed by the changes on the global world order, mainly inflicted by the effects of terrorism in the European societal dynamics. Following the need to have a win-win instrument with a functionalist, sector-based logic, the Treaty also launched the figure of the High Representative of the Union for Foreign Affairs and Security Policy as a key institutional actor with a challenging job profile: a dual role as External Relations Commissioner and High Representative for Common Foreign and Security 
Policy, with the additional responsibility of chairing the Foreign Affairs Council. For analytical purposes, it is relevant to highlight that the multitude of responsibilities attached to this particular actor makes (a priori) her/him a potential policy broker and a pivotal tool that was envisioned to pragmatically respond to the terrorism placing it within a global and functionalist logic; thus, global Europe. Borrowing from Mintrom, we introduced in our analytical framework the attributes, skills and strategies (Mintrom, 2019a, pp. 308-309) that are inherent to the HR as a political entrepreneur. It is particular interesting to observe the skills and strategies to fully understand the scope of the HR as a policy entrepreneur and broker in the EU CT policy framework and how their performance has been articulating amid Thin, Thick and Global Europe.

\section{Policy entrepreneurship framework, fear and policy change}

This article suggests a reconceptualisation of the framework of policy entrepreneurs, which is often referred to by the academic literature that discusses the role of institutions in European integration (Kaunert, 2010c). The concept of a policy entrepreneur is grounded in the works of Kingdon within the context of US politics. Kingdon (1984, p. 173) suggests a policy-making model starting with the identification of a problem (first stream), which is then followed by a search for alternative solutions (second stream) and a decision among these alternatives (third stream). How does policy change occur? According to Kingdon (1984), whilst streams largely flow independently from one another, they may come together at the time of a 'focusing event', such as a crisis. At that time, a window of opportunity opens for a short period of time, thereby enabling a policy entrepreneur to push for a new policy. Policy entrepreneurs, 'advocates [...] willing to invest their resources - time, reputation, money' (Kingdon, 1984, p. 188), stand at this window in order to propose, lobby for and sell a policy proposal. However, this conceptualisation needs to be extended by using Mintrom's insights (2019a), building on Kaunert's (2010c) work on supranational policy entrepreneurs. Kaunert (2010c) describes the ways in which political entrepreneurs can achieve this: (1) first mover advantage: SPEs need to come in faster with their proposals than their rivals; (2) persuasion strategy; and (3) alliances, where the SPE forms initial alliances with other powerful actors to create a bandwagon effect, whereby more actors will join the 'winning team'. Some resources are likely to help policy entrepreneurs in their endeavours, such as time, reputation, expertise, political connections, negotiating skills and an authoritative position in decision-making, amongst others (Kingdon, 1984, pp. 180-181).

According to Mintrom, policy entrepreneurs can be 'recognised by their efforts to promote significant policy change' (Mintrom \& Norman, 2009, p. 651). To achieve it and to implement a successful strategy, the policy entrepreneur needs to possess specific attributes that can be fostered. Amongst them: 'ambition, social acuity, credibility, sociality and tenacity' (Mintrom, 2000; Mintrom, 2019a; Mintrom \& Norman, 2009). Policy entrepreneurs may express their strengths differently in one or more domains when compared to others. Ambition, perhaps the first attribute of a policy entrepreneur, is innately related to the disposition to advance energy, time and a whole range of different resources in the expectation of profiting in the future (Cairney \& Jones, 2016; Kingdon \& Thurber, 1984; Mintrom, 2019a, p. 310) Policy entrepreneur's social acuity can be acknowledged either by the way they move within their policy networks or by their capacity to apprehend 
the dynamics of the mind-sets, motivations and apprehensions of the other actors in a specific policy context. Credibility is inbuilt to the success of a policy entrepreneur's strategies and it is inherently linked to the way he/she displays proficiency in a certain area or with the capacity to sustain solid arguments around a certain subject allowing them to perform as distinct prominent actors. Sociability and tenacity go hand in hand with their willingness to achieve their main targets. The first is structural when policy entrepreneurs look for supporters to uphold their ideas and policy agendas; sociability can be measured by the length and solidity of the coalitions they are able to build and, tenacity, is intimately linked to the capacity of holding an endurance focus to achieve the ultimate goals in their agenda.

Attributes are important, however, policy entrepreneurs mostly standout because of their particular skills, namely, 'strategic thinking, team building, collecting evidence, making arguments, engaging multiple audiences, negotiating and networking', which according to Mintrom, differ from attributes because they can be assimilated and developed (Mintrom, 2019a, p. 311). Strategic thinking is fundamental to move smoothly into the policy agenda and to be forward-looking when drawing strategies, especially in areas that are constantly evolving and mutating (Kalil, 2017; Mintrom, 2019a; Mintrom \& Norman, 2009). Team building is a skill that needs to be nurtured as policy entrepreneurs tend to be more successful if they are good team players; the stronger the team is, the more successful the strategy will be (Kingdon \& Thurber, 1984; Mintrom, 2019a; Mintrom \& Salisbury, 2015). Collecting evidence, as Kingdon suggested, is a very powerful skill that policy entrepreneurs may want to further develop as it allows them to uphold and guide the pursuit of their goals in the policy agenda (Kingdon \& Thurber, 1984). Making arguments is a core skill to build important alliances and more importantly to support the delineated strategy. Engaging multiple audiences is intrinsically linked to the capacity of making arguments and the capacity of following the path to the policy objective, while at the same time being able to deliver the same message to different audiences adapting the speech but keeping the soul of the narrative. Negotiating and networking are arguably the most important skills for a policy entrepreneur (Carrubba \& Volden, 2000; Mintrom, 2019a, p. 314). The art of negotiation is undeniably the key to expand the network of supporters and to decrease the friction amongst those against and, as a tool of conflict management, it is the skill that may standout a policy entrepreneur from a common policy broker. Lastly, networking acknowledged by the different exchanges and collaborative links between different actors and policy networks is important because a policy entrepreneur cannot withstand if he/she does not engage in an active way to participate in relevant networks that open doors to the achievement of the policy strategy.

Finally, the capacity to develop and implement the strategies that comprise the aptitude to 'problem framing, using and expanding networks, working with advocacy coalitions, leading by example and being able to scale up the change process' are inherently linked and dependant on both the attributes and skills (Mintrom, 2019a, p. 308). The quality and capacity of how a policy entrepreneur problem frames will ultimately define his/her ability to identify an issue as a problem (Ackrill et al., 2013; Knaggård, 2015). Policy entrepreneurs can only act as policy brokers and bring together the streams if they are astute when framing a problem. Problem framing may encompass different strategic political movements with the ultimate idea of manipulating how the audience 
interacts with a certain problem, and how this problem may collide or undermine with their particular concerns (Fisher et al., 1991; Mintrom, 2019a). Using and expanding the networks is a strategy that will endow policy entrepreneurs to achieve the support they need in the political and legislative space (Arnold et al., 2017; Mintrom, 2019a). The more support they have amid their tactical networks the sooner they will achieve their policy goals. Parallelly, it is also important working with advocacy coalitions as they will make ease the process of policy change. Advocacy coalitions are more than a network of supporters; they are stand as barometer to measure what is the level of support regarding a certain policy proposal. According to Mintrom, 'the composition of a coalition can convey the breath of support for a proposal' (Mintrom, 2019a, p. 318). Leading by example is not only inherent to previous described attributes such as social acuity but is also a vehicle of advancement of policy entrepreneurs' ideas and suggestions for policy change. A policy broker can only be efficacious if he/she manages to clearly demonstrate the validity and feasibility of the policy proposal. More, leading by example is picking the idea or proposal they want to trade within the policy agenda and to use it as a flagship. Lastly, policy entrepreneurs will only achieve their goals if they are competent scaling up change processes if they can ultimately capitalise and build synergies upon their advocacy endeavours (Mintrom, 2019a, 2019b; Mintrom \& Norman, 2009).

\section{Policy entrepreneurship and EU counter-terrorism - assessing the skills and strategies of the high representatives}

The role of High Representative for the Common Foreign and Security Policy was created by the Treaty of Amsterdam (Council of the European Union, 1997). It was shaped to respond the needs of endowing EU foreign policy with continuity, coherency and visibility (Helwig, 2017, p. 123; Piris, 2010, p. 245). Despite the review of the role by the Treaty of Nice (European Union, 2000), the functions were still contained and somewhat limited supporting the Presidency and the Council in matters of common foreign and security policy and, whenever necessary, assuming its diplomatic facet on behalf of the Council at the Presidency's request building bridges with third parties (Amadio Viceré, 2015, p. 4). The Treaty of Lisbon established the role of the High Representative and Vice-President of the EU, creating an effective platform for a new institutional approach to this policy at institutional level and smoothing over the inter-pillar incoherence. The role of the High Representative thus translated into a new institutional approach by merging and reinforcing the functions previously held by the High Representative for the Common Foreign and Security Policy, the Secretary General and the Commissioner for External Relations. The HR was conceived not only as the EU's diplomatic emissary, but also as a mediator with intergovernmental and supranational responsibilities (European Commission, 2012, p. 29). The new superposition of the HR, in addition to becoming a bridge between both EU institutions, now has direct responsibility for all the different dimensions of EU external relations (Bretherton \& Vogler, 2005, pp. 168-169; Piris, 2010 , p. 244; Vanhoonacker \& Reslow, 2010, p. 2). Assuming that one single individual would undertake the same three functions, colloquially defined as hats (Griller \& Ziller, 2008, p. 150; Piris, 2010, p. 243), has led many scholars to characterise this position as a true mission impossible (Dietrich, 2019; Euroactiv, 2009). The amendments to the functions of the HR are introduced in Article 18 and 27 TEU. They include a significant coordinating 
role, while introducing a hybridisation of HR functions that oscillates between the supranational and intergovernmental arena, with the aim of enhancing the robustness of institutional coherence between CFSP actors and other member states in the fight against terrorism. From a supranational standpoint, with regards to CFSP, and under the umbrella of 'ensuring the unity, consistency and effectiveness' of Union action, the HR additionally has the 'right of initiative', both in HR matters (CFSP), as Vice-President of the EU Commission on the matters External Relations managed by the Commission (De Ruyt, 2005, p. 15). The role of representativeness is also extended and now gives it the power to conduct ministerial political dialogues with third countries, not only CFSP issues, but also acting and actively participating as a policy entrepreneur in the Commission's external relations (Amadio Viceré, 2015, p. 2016). Concurrently, the HR also heads the Union's Special Representatives (EUSR), while also having the possibility of accompanying the work of the European Council, despite not being a member nor be able to vote (Denza, 2012; Helwig, 2015; Helwig \& Rüger, 2014). The wide range of HR representation functions also embody the roles concerning 'common foreign and security policy issues' and additionally, the task of representing the EU in 'international organizations and international conferences', including the United Nations Security Council. Lastly, the HR also heads the negotiation of "international agreements relating exclusively or principally to CFSP matters on behalf of the Union", aside from also shouldering the consultation and information obligations on CFSP matters towards the European Parliament. Given the transnational dimension of terrorism, the post-Lisbon era inaugurates the possibility for HR to actively participate in CFSP proposals, opening up the possibility of further extending the dialogue on such delicate matters as the strategy against terrorism, fight against organised crime and fraud, or even discuss deradicalization approaches with third countries. This competence that was previously solely with the member states, enables a whole new externalisation of EU security.

\section{(1) The policy entrepreneurs}

In his seminal work Agendas, Alternatives, and Public Policies, Kingdon briefly describes what qualities (Kingdon, 2013, p. 180) policy entrepreneurs should possess to achieve their objectives and avows that beyond being able to 'develop their ideas, expertise, and proposals well in advance of the time the window opens' [...] ]and 'the policy entrepreneur who is ready rides whatever comes along'.(Kingdon, 2013, pp. 181-182). Despite the centrality of the individual across his book, and notwithstanding the plentiful times Multiple Streams Framework has been employed by academics of different policy areas (Béland \& Howlett, 2016; Cairney \& Zahariadis, 2016), the debate around the importance of the individual, his attribute, skills and motivations have been largely put aside when compared to the attention given to the dynamics of stream coupling. According to Mintrom this might pose a problem: the full understanding of policy change is more than understanding the problem, the policy and the politics stream, it is also about understanding of what matter the policy entrepreneur is built - to examine if his readiness to ride any wave is conditioned by specific characteristics and features that make her/him standout and strive (Mintrom, 2019a, pp. 307-308; Mintrom \& Norman, 2009, p. 651). Failing to do this examination won't give us the whole picture and an analysis of how policy change occurs inside of the agenda will be incomplete. For that reason, and to 
break what he names a 'theoretical impasse', we need not only to closely observe the policy entrepreneurs as individuals, but also to understand how and why the contexts interfere and outline their actions (Mintrom, 2000; Mintrom \& Norman, 2009; Mintrom \& Vergari, 1996). This is of utmost importance when reflecting about the role of the HR as a policy entrepreneur and how this actor has been shaping the EU CT policy agenda. Hence, the following section shall outline the performance of each HR has been managing the agenda coupling throughout the evolution of terrorism as a metamorphotic problem.

The role of the EU HR celebrates twenty years of existence, having gone through a number of politically critical moments, particularly those that have shaken the security of the EU as a whole. Along this timeline, three personalities led the position of High Representative of the Union, all of them with different profiles, all marking the post at the institutional and instrumental level, but above all revealing the entrepreneurial power of HR. Despite being in function for more than a decade, the HR post continues to be shrouded in enormous ambiguity, either due to the complex nature relations between the Commission and the Council, or due to the hybrid nature of its functions that often oscillate between a powerful negotiating profile and diminished support administrative. However, we can say that the position was always shaped and reshaped by triggering events. Since its creation, the post of HR/VP has evolved and has increased the level and depth of interaction between the different EU bodies. Below a representation of the hat trilogy:

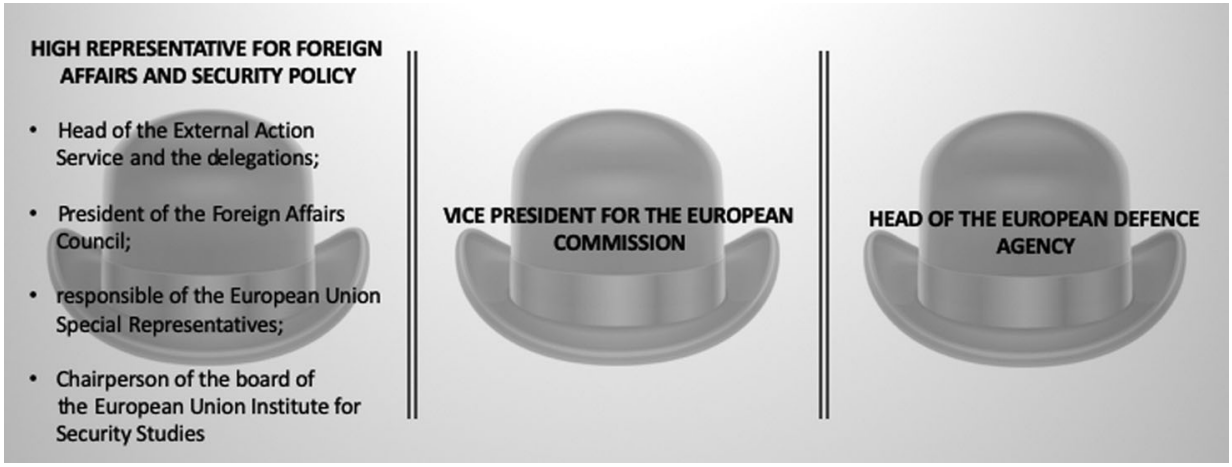

However, the role is yet to be properly defined and questionably, for that reason, the post continues to be perceived with a certain institutional indistinctness (Amadio Viceré, 2015, p. 6; Helwig \& Rüger, 2014, pp. 12-15; Schmidt, 2011, pp. 175-176). Although the depth and range of the institutional role remains blurred, using the lens of Kingdon and Mintrom may, on the other hand, help us to understand two things: first, the scope of the HR role as a policy entrepreneur shaping the EU CT policy agenda and second, if there were a job profile to be outlined for HR, what attributes and skills necessary should be taken into consideration to stand out as a policy entrepreneur. Pondering all the internal and external challenges the role has been facing since the creation of the post, we posit that this is not only relevant, but may also be a contribute to further research and policy developments around this subject. For that reason, borrowing from Mintrom, it is important to examine the performances and contributions of Javier 
Solana, Catherine Ashton and Federica Mogherini, observing how their individual attributes and acquired/learned skills, influenced their problem framing, how they positioned themselves inside the EU CT policy agenda. Ultimately, this will allow us to understand the oscillations of their strategies as EU CT policy brokers, mediators or diplomatic officers.

\section{(a) The beginning - Javier Solana's mandate}

Solana will keep to himself the feat of having been the first to answer Kissinger's question: 'What is the European phone number?' (Brunnstrom, 2009; Lefebvre \& Chopin, 2010). In the language of the four face of Europe, this represents the thick version of Europe. Solana's tenure as HR started in 1999 and ended in 2009. Looking at Solana's professional path and profile we can already assume that he possessed several attributes that would deeply influence his policy strategies during the years of his mandate. Ambition, social acuity, sociability, tenacity and a solid credibility would make him one of the most prominent political actors during this period. Moreover, his personal profile was described as a good listener, ready to approach all sides of the problem, with a flexible capacity to adapt to different interlocutors (Gallach, 2011, p. 11). His previous career as Spanish Minister of Foreign Affairs opened him his first window of opportunity that he competently took as post of Head of NATO between 1995 and 1999 (Boin et al., 2013, p. 84; Mintrom \& Luetjens, 2017, p. 15; Spence \& Bátora, 2015, p. 90). His years in NATO reinforced his atlanticist views, (Larivé, 2016, p. 165) and this would later become very visible in his different speeches at the Foreign Affairs Council and other contributions to the EU CT policy agenda (Bates, 1999; European Council, 2003, 2004; Solana, 2003, 2004). Subsequently, already in the role of HR, Solana lead the conception and development of the Common Security and Defence Policy (CSDP) and EU's Common Foreign and Security Policy (CFSP). His skills as proficient negotiator were demonstrated by achieving a peace deal in the Former Yugoslav Republic of Macedonia consolidating him as a credible policy broker (Blockmans \& Koutrakos, n.d., p. 61; Mintrom \& Luetjens, 2017, pp. 15-16; Solana, 2003). His strategic thinking and his capacity of negotiating and networking bequeathed him the capacity to make elaborate arguments, to address several and different audiences. However, there is one skill that certainly strengthen his capacity to explore the different windows of opportunities more than others - team building. Solana surrounded himself with a multi-disciplinary team that worked actively towards the implementation of his strategies (Spence \& Bátora, 2015, p. 92).

Solana's mandate is intrinsically linked with the seminal counter-terrorism institutionalisation and policies in the European Union. 9/11 had obviously influenced the course of action of the EU policies against terrorism, but, between the creation of the Counter-Terrorism Coordinator and the Madrid attacks of $11 \mathrm{M}$, Europe kept a mild inertia in what concerns the counter-terrorism policy agenda. 11/M (11 March 2004 terror attack on Madrid) was therefore taken as the 'wake-up' call to a more robust institutionalisation and more coherent counter-terrorism policies and tools. As the attack was assumed as a collective pain and an attack on European values, during this period all the steps forward were rarely questioned. George W. Bush's earlier global call for a united response against the transnational 'evil' triggered the initial adoption of the external and internal security framework (Argomaniz, 2009; De Vries, 2008; Kaunert \& Léonard, 2012, p. 423). The strategy he used to frame the Madrid bombings problem was allusive of a mastery of how to use networks, 
to build coalitions, to lead by example and to scale up the change process. The article in the Financial Times is a jump into the window of opportunity. In one single non-official document, he addressed EU institutions, civil society, Atlantic coalitions, he reaffirmed what European identity is, and, more importantly, he addressed the legislative measures to tackle what is at the very core of terrorism - fear (Solana, 2004). Counter-terrorism policies must be addressed considering the effects but also the understanding of grievance as a catalyst for terror attacks. He highlights the importance to manage fear with supportive legal instruments such as the European Arrest Warrant, border controls or counterterrorism financing, and he engaged multiple audiences: the objective of the article clearly underlined the importance of getting the message from the inside out and may itself be considered a visible point to show off the perfect three streams alignment (Solana, 2004). Solana personally engaged in the Action Plan on combating terrorism brought forward by the European Council and despite the limitations of his mandate under the Treaty of Amsterdam, he acted not only as a mediator between the Council and Commission, but also retained to himself the merits of policy entrepreneur during the aftermath of 9/11. Solana authored the European Security Strategy adopted by the European Council in 2003 identifying not only the globalised nature of terrorism but breaking old paradigms, namely in how to address these 'dynamic' threats (European Council, 2003). The number of speeches and media engagement is quite significant during this period and Solana personally engaged not only in designing the counter-terrorism strategy, but he actively sought to get public support for his political counter-terrorism strategy (Bates, 1999; Irish Times, 2003; País, 2000; Solana, 2004).

The year of 2004 and 2005 were heavily marked by a trigger-reaction policy period. After $11 \mathrm{M}$ and the London bombings, Solana created the Counter-Terrorism Office, designating Mr. Gijs de Vries as Counter-Terrorism Coordinator whose mission was to coordinate the Council's counter-terrorism tasks, supervising the implementation of the EU counter-terrorism strategy and playing the role of EU mediator in the fight against terrorism, under the pillars of 'prevent, protect, pursue and respond', introduced by EU Counter-Terrorism Strategy in 2005 (European Council, 2005). In 2007, Gilles de Kerchove replaced de Vries after three years of limited activity. Solana, once again, stepped forward announcing that the new CTC would have enhanced functions and he would be working in synergy with other EU institutions in order to effectively put in place the counter-terrorism strategy. In terms of intelligence cooperation, he was also involved as a policy entrepreneur bringing forward the Joint Situation Centre to start producing intelligence based classified assessments. Under his request, the Council of the European Union agreed in June 2004 to establish within SITCEN a Counter Terrorist Cell that would later become the European Union Intelligence Analysis Centre (EU INTCEN) (Bossong, 2012, pp. 77-78; Keohane, 2005, p. 15). He had previously shaped this outcome through several proposals to the Council and discursively in the released Summary remarks on Terrorism and Intelligence cooperation (European Council, 2004). However,

his biggest achievement was the development of his supporting bureaucratic organisation (...) When he was appointed in 1999, he had some seventy civil servants working for him. Ten years later when he left office, there were approximately 600-700 civil servants in Brussels directly reporting to him. (Dijkstra, 2011) 
Finally, in the words of the spokeswoman that shared with him 14 years within the EU institutions, we may sum up what made Solana a true policy entrepreneur - he created his own method tag for his strategy approach:

The Solana Method - a vision and tenacity, respect, discretion and at the same time appropriate visibility, he managed to lead a U-turn in many areas of EU diplomacy, crisis management and conflict resolution. His challenge was to ensure that Europe moved definitively from being a theatre to being an actor in the world scenery. (Gallach, 2011, p. 11)

\section{(a) Catherine Ashton's mandate}

The position of the HR after the Treaty of Lisbon became more complex and ambiguous, of supranational nature with the Commission, alongside the Member States, the Council, and the European External Action Service (Helwig \& Rüger, 2014; Vanhoonacker \& Pomorska, 2013, p. 1319). While the work of her predecessor never implicated a clear interaction with the Commission, Ashton's role clearly involved a more muscular dynamic that was beyond an intergovernmental relationship. Ashton oscillated between thin and thick Europe, highly functionalist, and, thus, finally moving towards thin Europe. Her job profile, with the Treaty of Lisbon, embodied a set of intergovernmental with supranational features, that, a priori, involved the prowess of networking, negotiating, engaging multiple audiences and strategic thinking to disentangle the many tensions raised amongst Council and the Commission (Laursen, 2016, p. 42; Radtke, 2012). Ashton's main task was to set up the EEAS and perhaps because she was an 'accidental diplomat,' her diplomatic and negotiating facet was very dim (O'Connor, 2010). Ashton was a totally newcomer, an unknown politician whose international relations experience was very short with no experience in brokering international agreements (McSmith, 2014). Her mandate will be forever linked to some distinctive features: she was the first HR with the new double hat formulation, she was the one setting up the entire EEAS from scratch while crossing the European economic crisis, and also started her mandate during another trigger-event: the Arab Spring. Despite being considered by many a weak post holder without much impact, in truth, she managed to quietly build her reputation as a policy entrepreneur by operationalising the EEAS in the first year of her tenure with the help of her negotiation skills (Christoffersen, 2011; Vanhoonacker \& Pomorska, 2013, p. 1321).

Ashton began her mandate at about the same time as the Arab Spring, and new warnings regarding a growing terrorist threat started to sound. The instability caused by the 'Arab Spring' riots opened new possibilities for al-Qaida to look for new niches in Africa and to rise again. The MI5 Director-General made it public that there were already signs of self-organisation in the UK and that there were already some British Jihad candidates. It also warned that there was a possibility that some would return to the UK and that this could pose a threat to European territory. Europol's own report also stated that the Arab revolutions and the economic crisis could increase the risk of terrorist attacks in the EU by Islamists (Hopkins, 2012). Kerchove also warned that the Arab Spring could mean enhanced danger and that one of his concerns was the 'dismantling of the security services in Tunisia and Egypt,' provoking 'a security vacuum'(...) and he publicly called for EU support saying 'that's where I see an urgent need for the EU to 
help'(Sommers, 2011). In northern Mali, radical Islamic groups closely linked to the terrorist organisation 'Al-Qaida in the Islamic Maghreb' (AQIM) controlled part of the territory. This was the first big warning towards the EU's southern neighbourhood's instability. Consequently, the EEAS released a new strategy focused solely on Sahel where it assumed a mid-long-term intervention in Sahel in order to counter terrorism and radicalisation at the source. In terms of being able to advance and couple the streams in the EU CT policy agenda, she was never truly proficient, although throughout her tenure she tried to make shy efforts to bring the conflict in Yemen to the agenda (Ashton, 2010), the need to tackle terrorism and radicalisation. As a potential policy entrepreneur, apparently, she did not capitalise on the window of opportunity opened by the attacks in European soil during her tenure, nor did she seem to exploit the importance of the changing nature of the terror attacks in Europe during those years.

Her policy entrepreneurship in the EU CT agenda was always discrete but she managed to work with advocacy coalitions from behind skilfully. Although, apparently, her position as policy broker was neither fish nor fowl, during her mandate she chaired the negotiations with Iran on nuclear issues that led to the Geneva Interim agreement on the Iranian nuclear programme, known as The Joint Plan of Action (P5+1 Powers, 2013). The Agreement was probably the greatest achievement of Ashton's agenda and it was achieved with some competent manoeuvres behind the limelight (Reuters, 2013). One episode that should be further examined is the Burgas attack on the 18th July 2012, in Bulgaria (Euroactiv, 2013; Spokesperson of EU High Representative et al., 2013). The episode occurred during the negotiations to achieve the Iranian nuclear agreement and it was probably one of her biggest achievement as policy entrepreneur - Israel and Bulgaria urged to say that the attack had the mark of Hezbollah and, although she was pressured to recognise it as a terrorist organisation, she kept her position focused on the need to further investigate the episode. While she underlined the need to identify and punish the perpetrators, she also insisted in pursuing diplomatic talks in order not to destabilise the relationship with Lebanon, where part of the group had its operations (Euroactiv, 2013; Pawlak, 2013a). This gave her some room to continue her contributions in the negotiations to achieve the deal, proving that her tenacity and ambition were actually very clear - the target was the success of the negotiations, what was later publicly recognised by her weighty counterpart, John Kerry (Kerry, 2014). Her personal and individual efforts were finally recognised and she managed to clean her image of being a merely bureaucrat (Blair, 2013; Pawlak, 2013b; Spiegel, 2013). In an interview at the Wilson Centre she disclosed her negotiating and mediating skills when asked about the Geneva II and Iran's participation: 'you have to have a political process, and you don't make peace with your friends. So this was always going to be about finding a way that you could move from this dreadful situation on the ground' (A Conversation With Catherine Ashton \& Wilson Center, 2013). Her achievements gave her the label of the quiet diplomat and all her accomplishments were always attained behind the spotlight she never enjoyed (McSmith, 2014; Mock, 2010). Drawing on Kingdon and Mintrom we can fairly recognise that Catherine Ashton was a policy entrepreneur, although not as clearly and straightforwardly for the EU Counter-terrorism agenda as Solana was, her policy entrepreneurship had few but clear targets that she successfully achieved - a functional EEAS and the Iranian Nuclear deal where she clearly managed to couple the streams. 
(a) Federica Mogherini's mandate: terrorism at home (again) and the internal/external nexus

Mogherini succeeded Ashton with only eight months of experience as Italian Foreign Minister. While she pursued global Europe, trying to encourage the intervention of global, extra-European actors such as the UN, it was only partially successful. Her choice was seen by many as victory of Prime-Minster Mateo Renzi (Bindi, 2014; Frascescon, 2014; Gardner, 2014; Howorth, 2015). She started her tenure with several important EU foreign and security policy issues, notably the Middle East Peace Process and the challenges posed by the expansion of ISIL in Iraq and Syria. From the beginning of her term, Mogherini advocated an active debate and effective investment in counter-terrorism policies. Her mandate, similarly to what happen during Solana's tenure, was also marked by several terror attacks on European soil such as, Charlie Hebdo and Bataclan in Paris, the bombings in Brussels, Nice, Manchester, London, Barcelona, Berlin, amongst others, and, the biggest political challenge the EU has faced in recent years, the so-called 'refugee crisis'.

The exercise of Mogherini's mandate differs greatly from others, namely through the vehicles she used to communicate with citizens and their counterparts. All the diplomatic machinery was oriented towards new technologies and often pronounced in advance on social media platforms, such as Twitter and Facebook, in order not only to spread the message faster, but especially to act autonomously. This translated into a significant number of statements between 2014 and 2019. This personal investment in addressing multiple audiences were a clear sign of a strategy to lead by example with a dynamic and forward-looking problem framing. Although as a HR she had her own official webpage, she created a new personal one where her speeches, public interventions and videos were daily updated and where she included a 'My Diary' section to speak in the first person to her audiences. ${ }^{1}$ This denotes very strong marks of personal investment, ambition and social acuity with a probable desire of building up a credibility that the post required. As with Solana, Mogherini somehow took advantage of the fact that there was unanimity about the terror attacks on European soil. This enabled her to become a policy entrepreneur in ways that had not been widely imagined before, reinforcing the spectrum of her message and thus shaping member states' own political decisions and policy action in the EU. Particularly, she actively worked towards the better integration of the internal/ external dimension of security and she highlighted the importance of the implementation of the European Agenda for Security linking the external and internal dimensions of the security realm (Euroactiv, 2014b; Mogherini, 2015a, 2015b). In her speech at the EU Global Strategy Conference in Barcelona, she mentioned terrorism as an example of the need to bridge the 'different dimensions of action', as one of the key issues for the EU InternalExternal Security Nexus (Mogherini, 2015a), that must be outlined under a consistent and responsible engagement framework:

A starting point for our work is the close link between our internal and external policies and the effect this has on our security. (...) I will focus on two main principles. One is consistency, the other is responsible engagement. Consistency means that our external and our internal action must be guided by the same interests and the same values. (...). (Mogherini, 2015a)

If for Solana the turning point had been the $11 \mathrm{M}$ attack, for Mogherini the paradigm shift was the Charlie Hebdo attack. In addition to joining the joint march in Paris $^{2}$ with the 
other heads of state, she became committed to addressing the issue of counter-terrorism on the agenda of the subsequent Council of Foreign Relations (FAC) where the core statement was

For the first time, there was a real awareness that we need to work together to fight a common threat. We took a decision within the FAC to cooperate in a much more active way than it has been the case so far

Moreover, as a demonstration of real commitment and need to build synergies, de Kerchove (CTC) was invited to attend this meeting (Mogherini, 2015b). The FAC after the Paris attacks in 2015 set the point of departure to a novel approach to terrorism, as Mogherini put it:

[...], probably for the first time, there was a real deep awareness of the need to work together and - I was surprised to know for the first time - the Foreign Affairs Council had a discussion with our EU Counter terrorism coordinator Gilles de Kerchove. I think this was not only a good exchange of views but also discussions on some decisions to take that is obviously only the first step. (Mogherini, 2015b)

Additionally, not only as a policy entrepreneur, but also as a bridge-maker bringing together the Council, the Commission, the Parliament and the member states, she skilfully stated:

the European Parliament to work on the Passengers name record, the PNR. This is not the competence of the Foreign Affairs ministers, but still they are politicians and members of the national cabinets; so our Council gave a strong call for moves in that direction, as well as the need to increase our work preventing financing of terrorist networks. (Mogherini, 2015b)

If it is true that the terrorism threat has been changing in shape and techniques, it is also true that it has changed more rapidly during Mogherini's mandate. From the overwhelming nature of big terrorist attacks, Europe is nowadays more and more used to the diffuse and pervasive nature of lone wolves' attacks that have been quite predominant during the last two years of her tenure. Moreover, for the last three years, the threats were also of a hybrid nature calling for different actions (Gressel, 2019; Mogherini, 2017). She engaged in a robust dialogue not only with different agencies but also underlined the need for a global response to a transnational dimension of terrorism - in this domain she managed to build different advocacy coalitions and scale up the change processes engaging in multi-stakeholder dialogues with the United Nations Office of Counter-Terrorism to strengthen multilateralism and global governance and EU's commitment to the fight against terrorism (United Nations Press, 2018), with the Arab League with whom she actively discussed the need for a joint effort to fight terrorism internally and externally (EEAS, 2016; European Parliament, 2015), with Turkey to cooperate against Islamic State (Euroactiv, 2014b; France 24, 2014; Kaca, 2015), with Sri Lanka promoting the financial Instrument to Stability and Peace to prevent violent extremism, build community resilience, and promote peace and tolerance (Wolters, 2019), and with Jordan building a partnership to fight terrorism and countering radicalisation (Mogherini, 2016a). Mogherini also engaged vigorously with the formulation of the European Neighbourhood Policy (Euroactiv, 2014a; Giannetti, 2014; Rettman, 2014). Regarding the southern neighbourhood, the HR also promoted several talks, namely during the EU-G5 
Sahel meeting that she hosted in June 2018 strengthening the idea that countering terrorism required common answers (EEAS, 2018a; Staudenmaier, 2019), clearly framing it is a common problem, but positioning herself and the EU as a mediator, negotiator and policy broker in a sharp attempt to stand-out in the EU CT policy agenda. Countering cyberthreats became one of the core areas of counter-terrorism within the policy agenda. In this area, Mogherini's policy entrepreneurship was quite active, not only at an internal level but also at the external one, notably in relation to NATO:

We are all affected, in Europe and beyond, and we all need to mobilise (...)We cannot do this alone, and we are not doing this alone our coordination with member states - starting from the digital one [Estonia] is constant, and we have a strong and important partnerships, starting with NATO" (...) We got to a stage of cooperation with NATO, especially in this field, that has no precedent in our history. (EEAS, 2017; Mogherini, 2017)

Mogherini was actively working towards greater harmonisation and joint synergies between the supranational and intergovernmental sphere that characterised the EU decision-making process, especially with regards to counter-terrorism. Perhaps the most consolidated incarnation of her vision is the European Union Global Strategy the document towards a stronger Europe (EEAS, 2018b; Le Gloannec, 2016; Vai, 2018) where, among other issues, counter-terrorism appears as a cornerstone to sustain the EU's external resilience (EEAS, 2018c). At an external level, Mogherini worked towards building as many partnerships as possible. Today, the outreach of the EEAS is quite remarkable. The launch of the Global Strategy has not only strengthened cooperation with the EU's neighbourhood, notably the Middle East, North Africa and the Western Balkans, but also with the Gulf Cooperation Council and the Arab League, which has also been strengthened by the placement of counter-terrorism and security experts across EU delegations and CSDP missions (EEAS, 2019). Throughout her term, Mogherini actively promoted all the functions under the hats she used (Dietrich, 2019).

\section{Conclusion}

Counter-terrorism is a crucial policy area for examining policy entrepreneurship by the HR. Previous research work acknowledged that while terrorism on Europe's soil has not been a recent phenomenon (Bossong, 2012; Chalk, 1996b; Engene, 2007; Kaunert \& Léonard, 2019), the $9 / 11$ terror attacks have represented a change of paradigm shift. Some of this research drew on Kingdon's Multiple Stream Framework to explain the evolution of the EU CT policy agenda (Argomaniz, 2009; Bossong, 2012; Bures, 2006; Coolsaet, 2010; Kaunert, 2010b). However, role of the policy entrepreneur as a pivotal actor for policy change (Argomaniz, 2009; Bossong, 2012; Kaunert, 2010b; Kaunert \& Giovanna, 2010; Kaunert \& Léonard, 2012) was not fully explored by previous works. For that reason, we brought into our analysis the combination of Kingdon's MSF and Mintrom's work on policy entrepreneurs. We analysed how the different HRs expressed themselves differently on the EU CT policy agenda and how their personal attributes and skills made them stand out as policy entrepreneurs. We dissected their different strategies on framing terrorism and settling the EU counter-terrorism policy agenda to that effect. In this sense, the first contribution of this article is towards a better understanding of the importance of the individual as a policy entrepreneur. Not only to express their willingness to invest their time, energy and reputation innovations (Kingdon, 2013, p. 122) but, in this particular 
case, to apprehend how the specific attributes, skills and strategies of each HR made them play different roles in the EU CT arena. Essentially, this is crucial to understand how they differently contributed to transform policy ideas into policy innovations and how these are inherently related to their abilities on 'strategic thinking, team building, collecting evidence, making arguments, engaging multiple audiences, negotiating and networking'(Mintrom, 2019a). Ultimately, it is vital to understand how their different motivations promoted policy change (Mintrom \& Norman, 2009, p. 651). Theoretically, this article also opens the doors to new domains of research, namely on the relevance and examination of the policy entrepreneur as vehicle of EU counter-terrorism policy change.

While examining the performances of each HR and their inputs to the EU CT policy agenda, a second element that became clearer: although, at the core, the problem stream was the same, terrorism, there were two different moments opening two very different big windows of opportunity - firstly, 9/11, which presented terrorism as an external and global threat and the need to cooperate at a comprehensive dimension and, the secondly, the Madrid and London bombings that brought out the need to address the threat from within. For that reason, these two event are arguably the biggest catalyst of the EU CT policy agenda (Wensink et al., n.d., p. 32) paving the way for the European Union Global Strategy as the most ambitious document brokered ever by an HR. This article thus outlined the role of the different HRs: Javier Solana, defender of the European civilizational status, the Judaeo-Christian matrix, resonated with the idea of a thick Europe. Catherine Ashton, after the profound changes introduced by the Treaty of Lisbon with the creation of the European External Action Service (EEAS), more with Thin Europe. Finally, Federica Mogherini, in her pragmatic response to terrorism, within a global and functionalist logic, corresponded more to global Europe. While the tenures of Solana, Ashton and Mogherini were very different; they were also influenced by their own personal attributes and skills. Solana was the typical policy entrepreneur, fitting impeccably Kingdon's profile, with long standing credibility built upon his skills developed as a diplomat, a mediator and a negotiator. He capitalised on the two big windows of opportunity and he managed to couple problem, policy and politics streams by framing terrorism skilfully, building networks of coalition and scaling up the change process. Leading by example and mastering his social acuity and ambition, Solana shaped his own role as HR and paved the way to the Treaty of Lisbon, where the role significantly evolved. Asthon's personality and attributes did not give her a shining start, especially because she was not expected to become the first HR/VP, nor had she the experience and flare of her predecessor. However, more than becoming an operational bureaucrat creating the EEAS, she managed to grab her window of opportunity succeeding with the Iranian nuclear agreement; her skills as a mediator and negotiator were widely praised when she came out as the pivotal actor during the conversations. She managed to be a policy entrepreneur as an HR in her own peculiar, quiet but effective way. Federica Mogherini began her tenure surrounded by voices claiming that her inexperience and short political career would hinder the tasks she had upfront. However, her ambition and tenacity soon proved that she was willing to invest her time and her efforts into an efficacious EU CT policy. Very early she straightened the collaborative ties with the CTC and, in the words of de Kerchove, she was 'extremely active on this [CT], and [the EU wanted to] engage more than before in the neighbourhood and fight against terrorist threats' (Denková, 2015). Also, Mogherini had the onus of having used the terrorism and counter-terrorism agenda in her favour 
since she managed to revive and foster synergies between the Commission, the EEAS, the anti-terrorism coordinator. Furthermore, she made good efforts dialoguing with the south and putting them (again) onto the EU CT policy agenda. During her tenure she addressed several times the evolving nature of terrorism and the need to tackle and understand the roots of radicalisation - her speech at the Global Counterterrorism Forum is a good example of that (Mogherini, 2016b). Her years as HR will be marked by her attempts to unite Europeans in response to terrorism always trying to avoid the growth of grievances and searching for a dialogue with the Muslim world (Mogherini, 2020; Vinocur \& Cienski, 2015). As a caveat to the argument of this article, although the HR built new bridges with new tools and powers, the EU institutional structure can sometimes also be a hindrance due to divisions, limits of mandates and competences between EU bodies. This may obstruct the much-desired horizontal coherence, and, at times, undermines the HR's policy entrepreneurship capacity. Factors such as the decision-making process and the ability and/or willingness to cooperate amongst member states, are the more current obstacles.

\section{Notes}

1. Please see federicamogherini.net

2. https://eeas.europa.eu/delegations/algeria/2504/statement-by-high-representativevicepresident-federica-mogherini-on-the-terrorist-attack-in-paris_en

\section{References}

Ackrill, R., Kay, A., \& Zahariadis, N. (2013). Ambiguity, multiple streams, and EU policy. Journal of European Public Policy, 20(6), 871-887. https://doi.org/10.1080/13501763.2013.781824

Amadio Viceré, M. (2015). From 9/11 to Da'esh: What role for the High Representative in the external dimension of EU counter-terrorism policies? IAI Working Papers, 15.

Andreeva, C. (2019). The EU's counter-terrorism policy after 2015-“Europe wasn't ready"- "but it has proven that it's adaptable". ERA Forum.

Argomaniz, J. (2009). Post-9/11 institutionalisation of European Union counter-terrorism: Emergence, acceleration and inertia. European Security, 18(2), 151-172. https://doi.org/10.1080/ 09662830903460103

Argomaniz, J., Bures, O., \& Kaunert, C. (2015). A decade of EU counter-terrorism and intelligence: A critical Assessment. Intelligence and National Security, 30(2-3), 191-206. https://doi.org/10.1080/ 02684527.2014.988445

Arnold, G., Long, L. A. N., \& Gottlieb, M. (2017). Social networks and policy entrepreneurship: How relationships shape municipal decision making about high-volume hydraulic fracturing. Policy Studies Journal, 45(3), 414-441. https://doi.org/10.1111/psj.12175

Ashton, C. (2010). Debates - Tuesday, 19 January 2010 - Situation in Yemen.

Bakker, E. (2012). A fear management approach to counter-terrorism. British Journal Of Criminology, 51(1), 75-94.

Bakker, E., \& Graaf, B. (2014). Towards a theory of fear management in the counterterrorism domain: A stocktaking approach. ICCT Research Paper.

Bates, S. (1999). Solana calls for voice to match EU might. The Guardian, 18 Nov.

Béland, D., \& Howlett, M. (2016). The role and impact of the multiple-streams approach in comparative policy analysis. Journal of Comparative Policy Analysis: Research and Practice, 18(3), 221-227. https://doi.org/10.1080/13876988.2016.1174410 
Bickerton, C. J., Hodson, D., \& Puetter, U. (2015). The new intergovernmentalism: European integration in the post-Maastricht Era. JCMS: Journal of Common Market Studies, 53(4), 703-722. https://doi.org/10.1111/jcms.12212

Biebuyck, W., \& Rumford, C. (2012). Many Europes: Rethinking multiplicity. European Journal of Social Theory - Eur J Soc Theory, 15(1), 3-20. https://doi.org/10.1177/1368431011423567

Bindi, F. (2014). The real meaning of Mogherini. Judy Dempsey's Strategic Europe.

Blair, D. (2013). Iran nuclear deal takes Catherine Ashton from 'zero' to hero, 24 Nov.

Blockmans, S., \& Koutrakos, P. (n.d.). Research handbook on the EU's common foreign and security policy. Edward Elgar Publishing.

Boin, A., Ekengren, M., \& Rhinard, M. (2013). The European Union as crisis manager: Patterns and prospects. Cambridge University Press.

Bongar, B., Brown, L. M., Beutler, L. E., Breckenridge, J. N., \& Zimbardo, P. G. (2006). Psychology of terrorism. Oxford University Press.

Bossong, R. (2012). The evolution of EU counter-terrorism: European security policy after 9/11 (1st ed.). Routledge.

Bretherton, C., \& Vogler, J. (2005). The European Union as a global actor. Routledge.

Brunnstrom, D. (2009). EU says it has solved the Kissinger question. Reuters, 20 Nov.

Buhari-Gulmez, D., \& Rumford, C. (2016). Towards a ("thick", "thin", or "parallel") European society? Understanding the dynamics of European multiplicity. Innovation: The European Journal of Social Science Research, 29(1), 41-55. https://doi.org/10.1080/13511610.2015.1055457

Bures, O. (2006). EU counterterrorism policy: A paper tiger? Terrorism and Political Violence, 18(1), 5778. https://doi.org/10.1080/09546550500174905

Cairney, P., \& Jones, M. D. (2016). Kingdon's multiple streams approach: What Is the empirical impact of this universal theory? Policy Studies Journal, 44(1), 37-58. https://doi.org/10.1111/psj.12111

Cairney, P., \& Zahariadis, N. (2016). Multiple streams approach: A flexible metaphor presents an opportunity to operationalize agenda setting processes. in N. Zahariadis Handbook of Public Policy Agenda Cheltenham: Edward Elgar.

Carrubba, C. J., \& Volden, C. (2000). Coalitional politics and Logrolling in legislative institutions. American Journal of Political Science, 44(2), 261-277. https://doi.org/10.2307/2669309

Chalk, P. (1996a). The development of the terrorist threat in Western Europe, 1968-89. In P. Chalk (Ed.), West European terrorism and counter-terrorism: The evolving dynamic (pp. 45-63). Palgrave Macmillan UK.

Chalk, P. (1996b). The nature of Contemporary terrorism: Problems of Definition. In P. Chalk (Ed.), West European terrorism and counter-terrorism: The evolving dynamic (pp. 9-24). Palgrave Macmillan UK.

Christoffersen, P. (2011). The creation of the European External Action Service'.

A Conversation with Catherine Ashton | Wilson Center. (2013). Woodrow Wilson Center.

Coolsaet, R. (2010). EU counterterrorism strategy: Value added or chimera? International Affairs (Royal Institute of International Affairs 1944-), 86(4), 857-873.

Council of the European Union. (1997). Treaty of Amsterdam amending the treaty on European Union, the treaties establishing the European communities and related acts.

Denková, A. (2015). EU counter-terrorism czar: Terrorists among asylum seekers? Unlikely. www. euractiv.com.

Denza, E.. (2012). The role of the high representative of the Union for foreign affairs and security policy. In H.-J. Blanke and S. Mangiameli (Ed.), The European Union after Lisbon (pp. 481-493). Springer.

De Ruyt, J. (2005). A Minister for a European Foreign Policy [Un ministre pour une politique étrangère européenne].

De Vries, G. (2008). The nexus between EU crisis management and counter-terrorism. The European Union and Crisis Management, 355-372. https://doi.org/10.1007/978-90-6704-561-2_20

Dietrich, B. (2019). Federica Mogherini.

Dijkstra, H. (2011). Solana and his civil servants: An overview of political-administrative relations. The High Representative for the EU Foreign and Security Policy: Review and Prospects, Baden-Baden: NOMOS Verlag. 
EEAS. (2016). Mogherini to League of Arab States: Only common response to terrorism can bring results. EEAS. (2017). EU drives international cooperation on cybersecurity; tests ability to respond to threats.

EEAS. (2018a). EU works with partners in Sahel to fight terrorism and trafficking.

EEAS. (2018b). A global strategy for the European Union.

EEAS. (2018c). Implementing the global strategy: EU delivers on security and defence.

EEAS. (2019). Shared view: the demand for civilian CSDP will remain high [online]. EEAS - European Commission. Retrieved October 4, 2019, from https://eeas.europa.eu/delegations/libya/65729/ shared-view-demand-civilian-csdp-will-remain-high_tg.

Engene, J. O. (2007). Five decades of terrorism in Europe: The TWEED dataset. Journal of Peace Research, 44(1), 109-121. https://doi.org/10.1177/0022343307071497

Euroactiv. (2009). Solana leaves Ashton 'impossible job description'. www.euractiv.com.

Euroactiv. (2013). Burgas attack: EU's Ashton makes no mention of Hezbollah. www.euractiv.com.

Euroactiv. (2014a). Mogherini: Russia is no longer the EU's strategic partner. www.euractiv.com.

Euroactiv, R. (2014b). Mogherini calls for greater EU-Turkey alignment against Islamic State. www. euractiv.com.

Euroepan Union. (2000). Treaty of Nice amending the Treaty on European Union, the Treaties establishing the European Communities and certain related acts.

European Commission. (2012). Treaty on European Union.

European Council. (2003). European Security Strategy.

European Council. (2004). Summary of remarks by Javier SOLANA, EU High Representative for the CFSP, on Terrorism and Intelligence Co-operation.

European Council. (2005). The European Union Counter-Terrorism Strategy.

European Parliament. (2015). Resolution on relations between the EU and the League of Arab States and cooperation in countering terrorism.

Fisher, R., Ury, W. L., \& Patton, B. (1991). Getting to yes: Negotiating agreement without giving in (Revised edition). Penguin Books.

France 24. (2014). EU calls for greater 'alignment' with Turkey over IS threat, Dec 9.

Frascescon, S. (2014). Renzi's victory: Mogherini becomes high representative. ECFR.

Gallach, C.. (2011). Preface and personal remarks. In G. Müller-Brandeck-Bocquet and C. Rüger (Ed.), The high representative for the EU foreign and security policy - review and Prospects (pp. 11-16). Nomos Verlagsgesellschaft $\mathrm{mbH} \& \mathrm{Co}$. KG.

Gardner, A. (2014). Federica Mogherini: the promotion of inexperience. POLITICO, 3 Sep.

Giannetti, R. (2014). Mogherini broke up with Russia: "No longer a strategic partner" - Eunews.

Gressel, G. (2019). Protecting Europe against hybrid threats.

Griller, S., \& Ziller, J. (2008). The Lisbon Treaty: EU constitutionalism without a constitutional treaty? Springer.

Helwig, N.. (2015). The high representative of the union: The quest for leadership in EU foreign policy. In D. Spence and J. Batora (Ed.), The European external action Service (pp. 87-104). Springer.

Helwig, N. (2017). Agent interaction as a source of discretion for the EU High Representative. In T. Delreux, \& J. Adriaensen (Eds.), The Principal Agent model and the European Union (pp. 105-129). Springer International Publishing.

Helwig, N., \& Rüger, C. (2014). In search of a role for the high representative: The legacy of Catherine Ashton. The International Spectator, 49(4), 1-17. https://doi.org/10.1080/03932729.2014.956423

Hopkins, N. (2012). MI5 warns al-Qaida regaining UK toehold after Arab spring. The Guardian, 25 Jun. Howorth, J. (2015). Is Federica Mogherini to make a real difference? Friends of Europe.

Huddy, L., Feldman, S., Lahav, G., \& Taber, C. (2003). Fear and terrorism: Psychological reactions to 9/ 11. Framing terrorism: The news media, the government, and the public, 255-78.

Irish Times. (2003). EU security strategy aims to build a safer, fairer, more united world. The Irish Times, 23 Sep.

Kaca, E. (2015). The Labours of HR Federica Mogherini: Her pursuit of a strategy and effectiveness. The Polish Institute of Foreign Affairs, (No. 14 (77)).

Kalil, T. (2017). Policy entrepreneurship at the White House. Innovations: Technology, Governance, Globalization, 11(3-4), 4-21. https://doi.org/10.1162/inov_a_00253 
Kaunert, C. (2010a). Europol and EU counterterrorism: International security actorness in the external dimension. Studies in Conflict \& Terrorism, 33(7), 652-671. https://doi.org/10.1080/1057610X. 2010.484041

Kaunert, C. (2010b). Towards supranational governance in EU counter-terrorism? - The role of the Commission and the Council Secretariat. Central European Journal of International \& Security Studies, 4(1), 8-31.

Kaunert, C. (2010c). European Internal Security: Towards Supranational Governance in the Area of Freedom, Security and Justice?. Manchester: Manchester University Press.

Kaunert, C., \& Giovanna, M. D. (2010). Post-9/11 EU counter-terrorist financing cooperation: Differentiating supranational policy entrepreneurship by the Commission and the Council Secretariat. European Security, 19(2), 275-295. https://doi.org/10.1080/09662839.2010.507246

Kaunert, C., \& Léonard, S. (2012). Introduction: Supranational governance and European Union security after the Lisbon Treaty-Exogenous shocks, policy entrepreneurs and 11 September 2001. Cooperation and Conflict, 47(4), 417-432. https://doi.org/10.1177/0010836712464592

Kaunert, C., \& Léonard, S. (2019). The collective securitisation of terrorism in the European Union. West European Politics, 42(2), 261-277.

Keohane, D. (2005). The EU and counter-terrorism. Centre for European Reform London.

Kerry, J. (2014). John Kerry on Twitter: 'Saying thank you to my friend Cathy Ashton: grateful for her outstanding work as \#EU High Rep/key role in \#IranTalks. http://t.co/bot9vm7G6r' / Twitter [online]. Twitter. Retrieved May 24, 2020, from https://twitter.com/JohnKerry/status/527645521243279360.

Kingdon, J. (1984). Agendas, Alternatives, and Public Policies. Boston: Little Brown.

Kingdon, J. W. (2013). Agendas, alternatives, and public policies. Pearson Education Limited.

Kingdon, J. W., \& Thurber, J. A. (1984). Agendas, alternatives, and public policies. Little, Brown Boston. Knaggård, Å. (2015). The multiple streams framework and the problem broker. European Journal of Political Research, 54(3), 450-465. https://doi.org/10.1111/1475-6765.12097

Larivé, M. H. A. (2016). Debating European Security and Defense policy: Understanding the complexity. Routledge.

Laursen, F. (2016). The EU's Lisbon Treaty: Institutional choices and implementation. Routledge.

Lefebvre, M., \& Chopin, T. (2010). Three Phone Numbers for Europe: Will the Lisbon Treaty Make the European Union More Effective Abroad? Brookings.

Le Gloannec, A.-M. (2016). EU global strategy. Expert Opinion. European Union Institute for Security Studies.

McSmith, A. (2014). The quiet diplomat: Catherine Ashton - recognised and admired in all the world's troubled countries, yet ridiculed at home. The Independent, $7 \mathrm{Mar}$.

Mintrom, M. (2000). Policy entrepreneurs and school choice. Georgetown University Press.

Mintrom, M. (2019a). So you want to be a policy entrepreneur? Policy Design and Practice, 2(4), 307323. https://doi.org/10.1080/25741292.2019.1675989

Mintrom, M. (2019b). Policy entrepreneurs and dynamic change. Elements in Public Policy.

Mintrom, M., \& Luetjens, J. (2017). Policy Entrepreneurs and Foreign Policy Decision Making.

Mintrom, M., \& Norman, P. (2009). Policy entrepreneurship and policy change. Policy Studies Journal, 37(4), 649-667. https://doi.org/10.1111/j.1541-0072.2009.00329.x

Mintrom, M., \& Salisbury, C. (2015). Policy entrepreneurs, creative teamwork, and policy change. 129-145.

Mintrom, M., \& Vergari, S. (1996). Advocacy coalitions, policy entrepreneurs, and policy change. Policy Studies Journal, 24(3), 420-434. https://doi.org/10.1111/j.1541-0072.1996.tb01638.x

Mock, V. (2010). French 'sexism' blamed for attacks on Baroness Ashton | The Independent. Independent, 16 Feb.

Mogherini, F. (2015a). Speech of the HR/VP Federica Mogherini -The EU Internal-External Security Nexus: Terrorism as an example of the necessary link between different dimensions of action.

Mogherini, F. (2015b). Remarks by High Representative/Vice-President Federica Mogherini at the press conference after the Foreign Affairs Council.

Mogherini, F. (2016a). Remarks by High Representative/Vice-President Federica Mogherini at the press conference with the Foreign Minister of Jordan, Nasser Judeh. 
Mogherini, F. (2016b). Speech by Federica Mogherini at this years Global Counter Terrorism Forum Ministerial Meeting.

Mogherini, F. (2017). Speech by the High Representative/Vice-President Federica Mogherini at the conference 'Hybrid threats and the EU: State of play and future progress'.

Mogherini, F. (2020). (20) Federica Mogherini on Twitter: 'Tunisia, Kuwait, France: Europe and Arab world united as victims and in the response. Terrorists want to divide us, they unite us even more' / Twitter [online]. Twitter. Retrieved May 25, 2020, from https://twitter.com/federicamog/status/ 614417129450942465.

O'Connor, S. (2010). The accidental diplomat. E! Sharp, 12-14.

P5+1 Powers, I.R. of I. (2013). Joint Plan of Action.

País, E. E. (2000). El comisario europeo Patten acusa a Solana de 'usurpar' sus tareas en política exterior. El País, 8 Jun.

Pawlak, J. (2013a). EU's Ashton floats plan to break Hezbollah deadlock. Reuters, 17 Jul.

Pawlak, J. (2013b). Iran success of EU's Ashton keeps Brussels in the game. Reuters, 27 Nov.

Piris, J.-C. (2010). The Lisbon Treaty: A legal and political analysis. Cambridge University Press.

Radtke, K. (2012). The EU's common foreign and security policy (CFSP) after the Lisbon Treaty: supranational revolution or adherence to intergovernmental pattern?

Rettman, A. (2014). Mogherini more hawkish on Russia in EP hearing. EUobserver.

Reuters. (2013). Interim nuclear agreement between Iran and six powers. Reuters, 24 Nov.

Rumford, C. (2014). European multiplicity (Edición: Unabridged edition). Cambridge Scholars Publishing.

Schmidt, J. (2011). The High Representative, the President and the Commission-competing players in the EU's external relations: The case of crisis management. In P.J. Cardwell (Ed.), EU external relations Law and policy in the post-Lisbon Era (pp. 161-180). Springer

Solana, J. (2003). A joint effort for peace and stability. Der Tagesspiegel, 16 Dec.

Solana, J. (2004). Three ways for Europe to prevail against the terrorists. Financial Times, 25 Mar.

Sommers, J. (2011). EU anti-terror chief highlights Arab Spring risks. Reuters, 5 Sep.

Spence, D., \& Bátora, J. (2015). The European external action service: European diplomacy PostWestphalia. Springer.

Spiegel, P. (2013). EU foreign policy chief Lady Ashton comes of age in Iran talks, 26 Nov.

Spokesperson of EU High Representative, the spokesperson of EU High Representative, Catherine Ashton, and EU High Representative Catherine Ashton. (2013). Statement by the spokesperson of EU High Representative Catherine Ashton on Bulgaria's announcement regarding the outcome of the Burgas attack investigation.

Staudenmaier, R. (2019). EU's Federica Mogherini urges action on terror threat in Sahel | DW | 12.07.2019. DW.COM.

Stout, C. E. (2004). Psychology of terrorism: Coping with the continued threat. Greenwood Publishing Group. United Nations Press. (2018). European Union, United Nations to strengthen partnership on counterterrorism - press release.

Vai, L. (2018). A joined-up Union in counterterrorism and public diplomacy. IAl Istituto Affari Internazionali. Vanhoonacker, S., \& Pomorska, K. (2013). The European external action service and agenda-setting in European foreign policy. Journal of European Public Policy, 20(9), 1316-1331. https://doi.org/10. 1080/13501763.2012.758446

Vanhoonacker, S., \& Reslow, N. (2010). The European external action service: Living forwards by understanding backwards. European Foreign Affairs Review, 15(1), 1-18.

Vinocur, N., \& Cienski, J. (2015). Terror attacks rock France, Tunisia and Kuwait. POLITICO, 26 Jun.

Wensink, W., Warmenhoven, B., Haasnoot, R., Wesselink, R., Van Ginkel, B., Wittendorp, S., Paulussen, C., Douma, W., Boutin, B., Güven, O., \& Rijken, T. (n.d.). The European Union's Policies on CounterTerrorism Relevance, Coherence and Effectiveness. 01-01-2017.

Wolters, J. (2019). Press Release - European Commission steps up support to counter-terrorism, the prevention of violent extremism and peacebuilding in Sri Lanka. 